\title{
Ornithonyssus sylviarum (Acari: Macronyssidae) parasitism among poultry farm workers in Minas Gerais state, Brazil
}

\author{
Cristina Mara Teixeira1 ${ }^{1}$ Tiago Mendonça de Oliveira ${ }^{2 *}$ Amanda Soriano-Araújo ${ }^{3}$ (D) \\ Leandro do Carmo Rezende ${ }^{4}(\mathbb{D})$ Paulo Roberto de Oliveira ${ }^{2 \dagger}$ \\ Lucas Maciel Cunha ${ }^{5}$ Nelson Rodrigo da Silva Martins ${ }^{2}$ (D)
}

\begin{abstract}
${ }^{1}$ Ministério da Agricultura Pecuária e Abastecimento (DIPOA), Brasília, DF, Brasil.
${ }^{2}$ Departamento de Medicina Veterinária Preventiva da Escola de Veterinária da Universidade Federal de Minas Gerais (UFMG), 31270-901, Belo Horizonte, MG, Brasil. E-mail: tiago0725@gmail.com. "Corresponding author. In memoriam.

${ }^{3}$ Instituto Federal de Minas Gerais (IFMG), Bambuí, MG, Brasil.

${ }^{4}$ Laboratório Federal de Defesa Agropecuária (LFDA), Pedro Leopoldo, MG, Brasil.

${ }^{5}$ Fundação Ezequiel Dias, Belo Horizonte, MG, Brasil.

ABSTRACT: Ornithonyssus sylviarum is a hematophagous mite present in wild, domestic, and synanthropic birds. However, this mite can affect several vertebrate hosts, including humans, leading to dermatitis, pruritus, allergic reactions, and papular skin lesions. This study evaluated the epidemiological characteristics of $O$. sylviarum attacks on poultry workers, including data on laying hens, infrastructure and management of hen houses, and reports of attacks by hematophagous mites. In addition, a case of mite attack on a farm worker on a laying farm in the Midwest region in Minas Gerais is presented. It was found that $60.7 \%$ farm workers reported attacks by hematophagous mites. Correspondence analysis showed an association between reports of mite attacks in humans with (1) presence of $O$. sylviarum in the hen house, (2) manual removal of manure by employees, and (3) history of acaricide use. The specimens collected from the location were confirmatively identified as O. sylviarum. O. sylviarum attacks ave not been reported when manure was removed in a shorter time interval and did not use acaricide in the sheds when the removal was done by manure conveyor belt. Parasitism by O. sylviarum should be considered a relevant occupational hazard affecting employees working in direct contact with commercial egg-laying hens in Minas Gerais. We emphasized the need to monitor hen infestations by this mite to improve the development of mite control strategies.
\end{abstract}

Key words: Ornithonyssus sylviarum, skin lesions, mites, hen houses, occupational hazard.

Parasitismo de Ornithonyssus sylviarum (Acari: Macronyssidae) em trabalhadores de avicultura no Estado de Minas Gerais, Brasil

RESUMO: Ornithonyssus sylviarum é um ácaro hematófago de aves silvestres, domésticas e sinantrópicas. No entanto, este ácaro pode afetar vários hospedeiros vertebrados, incluindo humanos, levando a dermatites, prurido, reações alérgicas e lesões cutâneas papulosas. O presente estudo avaliou os aspectos epidemiológicos do ataque de O. sylviarum em trabalhadores de granjas avicolas e descreveu um relato de caso em uma granja de postura. Este estudo utilizou um banco de dados secundário com informações sobre as poedeiras, infraestrutura e manejo dos galinheiros e relatos de ataques por ácaros hematófagos. Foi apresentado um caso de ataque de ácaro a um trabalhador rural no Centro-Oeste em Minas Gerais. Houve uma frequência de 60,7\% de trabalhadores que relataram ter sido atacados por ácaros hematófagos em fazendas. A análise de correspondência mostrou uma associação entre relatos de ataques de ácaros em humanos com (1) presença de O. sylviarum na fazenda, (2) remoção manual de esterco por funcionários da fazenda e (3) histórico de uso de acaricidas. Os espécimes coletados do local foram identificados como O. sylviarum. Não há ataques de O. sylviarum, quando a remoçãodo esterco é feita em menor intervalo de tempo, e não se utiliza acaricida nos galpões quando a remoção é feita por esteira transportadora de esterco. Conclui-se que o parasitismo por $O$. Sylviarum deve ser considerado como um risco ocupacional relevante, que afeta trabalhadores que trabalham diretamente com poedeiras comerciais em Minas Gerais. Ressaltamos a necessidade de monitorar as infestações de aves por esse ácaro, a fim de melhorar o desenvolvimento de estratégias de controle.

Palavras-chave: Ornithonyssus sylviarum, lesões cutâneas, ácaros, galpões, risco ocupacional.

\section{INTRODUCTION}

Ornithonyssus sylviarum (CANESTRINI \& FANZAGO, 1877), also referred to as the northern fowl mite, is an ectoparasite infesting domestic and wild birds worldwide (AXTELL \&ARENDS, 1990). This arthropod species is a hematophagous mite reported in chicken reared in industrial poultry systems and in other species of birds. It is considered a pest in layer poultry management and is an ectoparasite of significant economic importance for commercial poultry industries of the New World (DEVANEY, 1978; MULLENS et al., 2009; MURILLO \& MULLENS, 2017). 
In Brazil, O. sylviarum was first reported in the 1970s in laying hens from farms located in the southern region of Minas Gerais State (FACCINI \& MASSARD, 1974). Subsequently, new reports on the presence of this ectoparasite were established in other commercial systems with laying hens on the south-eastern and southern regions of the country (PEREIRA et al., 1977; FACCINI, 1987). In São Paulo State, a study on the occurrence of hematophagous mites in layer poultry showed that O. sylviarum was present in $48.8 \%$ of the 43 farms visited (TUCCI et al., 1996). More recently, a study of 43 commercial farms in Minas Gerais State, with the aim to determine the main risk factors for the occurrence of hematophagous mites, revealed that $O$. sylviarum was the most frequent mite species in these systems, being present in more than half $(53.48 \%)$ of the evaluated farms (CUNHA, 2013).

Economically, $O$. sylviarum has been considered as the most important poultry ectoparasite in the United States, where losses in poultry industry exceeded US\$ 68 million in 1974 (DEVANEY, 1979). Studies have shown that mite infestations may lead to deficits of US\$ $0.07-0.10$ per laying hen in 10 weeks (MULLENS et al., 2009).

Although, chicken is the preferred host, in their absence, O. sylviarum can affect several vertebrate hosts, including humans, leading to possible dermatitis, allergic respiratory disease, or both (KNEE \& PROCTOR, 2007; TÉLLEZ et al., 2008). In poultry farms, parasitism in humans by O. sylviarum occurs mainly during management practices, including during egg collection, and is common when the level of mite infestation in hen houses is high.

It is important to note that in urban areas, human infestations may also occur, which are related to synanthropic birds such as pigeons that may be infested by mites. According to AKDEMIR et al. (2009), the nests of these birds are usually located on roofs, near windows, or on air conditioners. When this occurs, public places such as schools and hospitals can be affected. Cases of acariasis have been attributed to mesostigmatid mites in human hospitals, houses, and other buildings. However, only few studies have analyzed these mite infestations as an endemic occupational problem to layer poultry farm workers in Brazil.

Considering the economic, productive, and health significance of the commercial poultry industry and the potential occupational health hazard caused by the parasite, an epidemiological study of ectoparasitism by $O$. sylviarum in layer farm employees was conducted.

\section{MATERIALS AND METHODS}

This study was conducted based on the findings of a previous study that aimed to evaluate the epidemiological characteristics of hematophagous mite infesting layer farms in Minas Gerais State, Brazil (CUNHA, 2013) and to describe a hematophagous mite attack during a study,which aimed to test a proposal of strategic chemical control of O. sylviarum (TEIXEIRA, 2016). A database was adapted from the study by CUNHA (2013) and structured based on information from 402 hen houses in 42 commercial properties regarding the occurrences of hematophagous mite attacks on farm workers, method and interval of manure removal, chemical control with acaricides, and presence or absence of mite species. Some parts of the data in this study were obtained from an epidemiological questionnaire applied in poultry farms March to June of 2012. The present variables in the database were dichotomized or categorized. Additionally, this study presented a case report of $O$. sylviarum infestation on a laying farm.

In this study, to evaluate a strategic control of $O$. sylviarum on birds, a case of a farm worker reporting that she was attacked by mites in March 2015 in a poultry farm located in the Midwest region of Minas Gerais was evaluated. During visual inspection, mites were not observed on the worker's body; although, mites were collected in the hen houses. These mites were preserved in $70 \%$ alcohol and sent to the Universidade Federal de Minas Gerais, Laboratory of Parasitic Diseases of Domestic Animals from the Preventive Veterinary Medicine Department for identification.

The confirmation and identification of the hematophagous mite species were performed using the morphological characterization key of Moss (1968) and FACCINI (1987), after the preparation of slides for optical microscopy. The mites were placed on slides containing lactophenol solution for clarification. Subsequently, the specimens were removed and immersed in 70\% alcohol for 24 hours, and the slides were prepared in Hoyer's medium (FLECHTMANN, 1975; KRANTZ, 1978).

To elucidate the geographical distribution of hematophagous mite attacks on workers, a georeferencing map containing microregions that have farms with these characteristics was constructed using the QGIS software 2.18.1 (QGIS, 2016) (Figure 1). Direct and indirect information regarding the participants in this study, such as workers and farm owners, were undisclosed. 


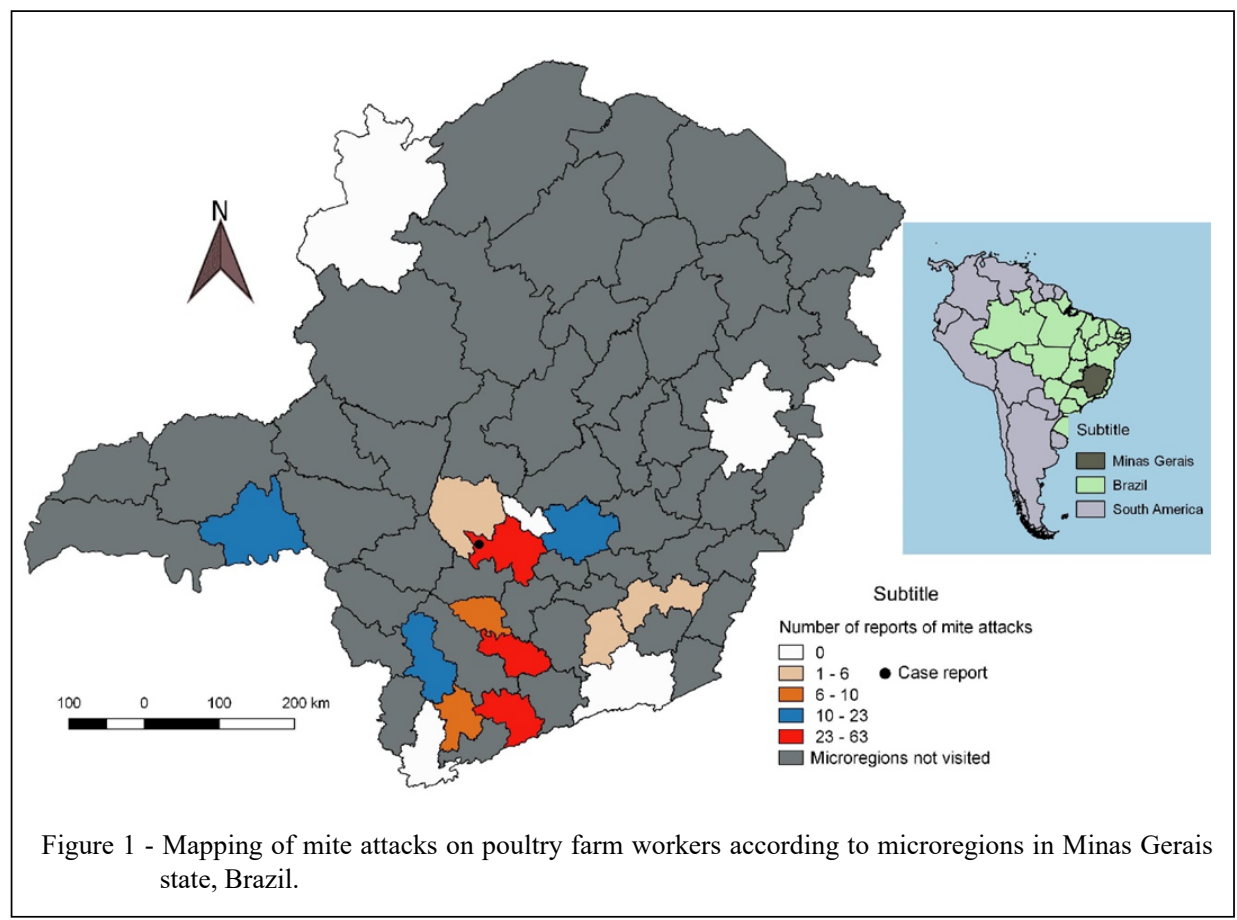

Variables present in the correspondence model were primarily screened using Pearson's chisquared test $(\mathrm{p} \leq 0.05)$. The selected variables were assessed using Multiple Correspondence Analysis (MCA) to evaluate possible associations through graphic figures. MCA graphs were plotted using the statistical software $\mathrm{Stata}^{\mathbb{\circledR}} / \mathrm{SE} 12$ (STATACORP, 2011). The three first axis generated by the analysis were interpreted by evaluating the proximity between the variables and the accumulated inertia, with an established cut-off of above $40 \%$, according to MINGOTI (2005).

\section{RESULTS AND DISCUSSION}

In the analyzed database, a frequency of $60.7 \%$ of workers who reported mite attacks was observed. The MCA graph characterizing mite attack reports presented an accumulated chi-squared value of $76.33 \%$ (Figure 2). The position in a third dimension is shown in parentheses. The variables used for the graphical presentation of correspondence are presented in table 1 with their respective captions and abbreviations. The appraised variables in the MCA graph are present inside the circles.

According to the correspondence analysis, an association between reports of mite attacks and the presence of $O$. sylviarum in the sheds, with the manual removal of manure and chemical control with acaricides, was observed. Manure removal interval 1 was associated with the absence of mite bites.

In addition to these results, a case report was evaluated during a visit to monitor strategies aiming to control O. sylviarum. During the visit, a farm worker reported a "chicken lice attack" (Figure. 3A). The mites present in the sheds were identified following some characteristics, such as: $O$. sylviarum adult anal shields have a teardrop-shaped anal plaque (Figure 3B, 3C), these mites are generally smaller (ca. 0.6 $\mathrm{mm}$ ), in addition to claw-shaped chelicerae. During the evaluation of the lesions, it was verified that it was parasitism caused by $O$. sylviarum since no other ectoparasites were reported in the sheds and birds. Additionally, the chickens present in same environment had a high degree of mite infestation, with a score between 6 and 7 (ARTHUR \& AXTELL, 1983), equivalent to 1.001 to over 10.000 mites per hen (Figure 3D).

High mite infestation in chickens contributed to greater dispersion inside the sheds since $O$. sylviarum can actively fall or leave the birds in search for other hosts, which are found in the facilities and in the manure under the cages 


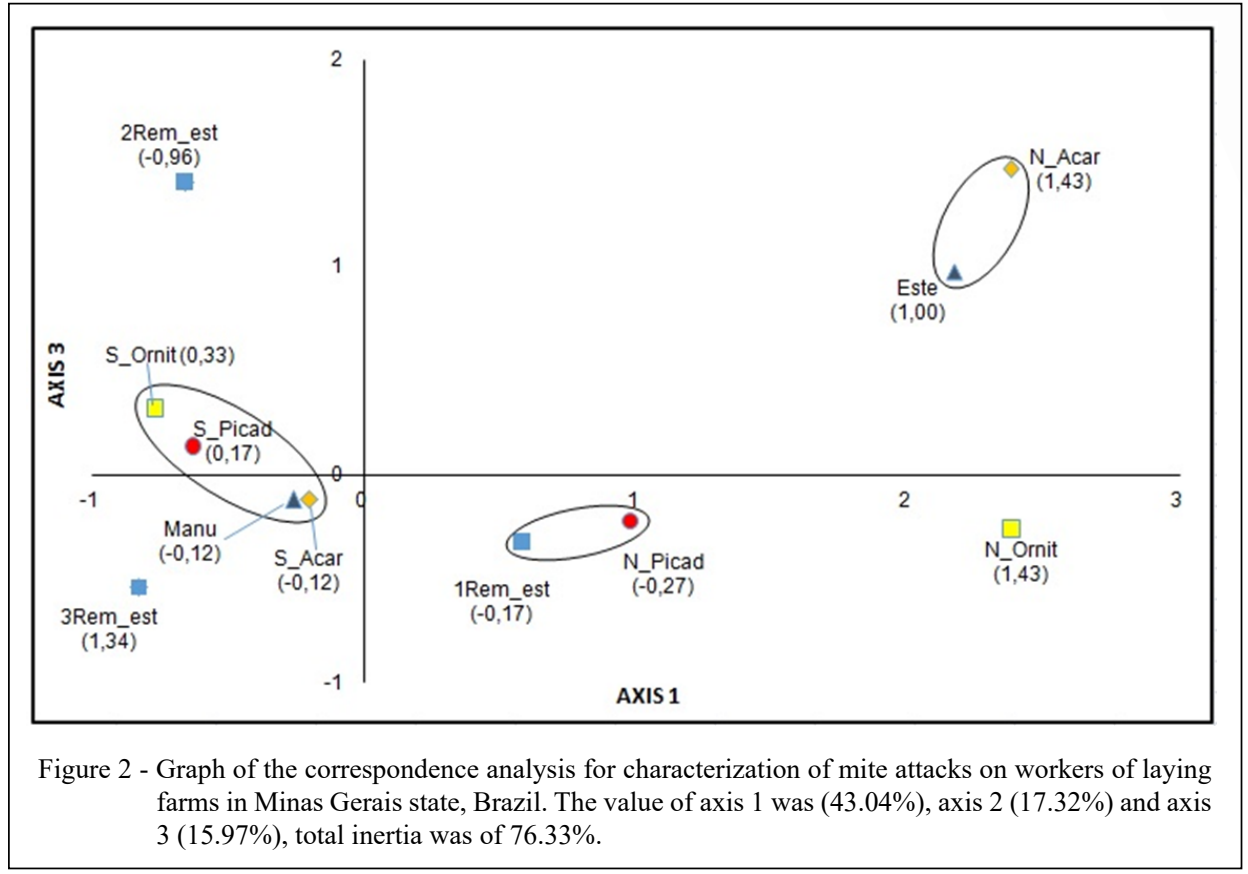

(DEVANEY, 1978; GUIMARÃES et al., 2001). The accumulation of manure contributed to the prolonged stay of $O$. sylviarum below the cages and to an increased chance of proliferation. This hypothesis was based on theresearch by MULLENS et al. (2001), who described the dispersal capacity of $O$. sylviarum even if there are empty cages between birds. Mite displacement and its possible fall in the manure could contribute for its presence on the excreta, resulting in probable infestations in chickens and humans.
The lower the time period that wastes stay below the cages, the lower the risk of $O$. sylviarum parasitism in humans.

It was found that hen houses that perform manual removal of manure or tend to leave it below the cage for a longer time period use acaricides more frequently to control these ectoparasites. However, farms that periodically remove the manure or do so through manure conveyor belt do not useacaricide (OLIVEIRA et al., 2018; REZENDE et al., 2019).

Table 1 - Variables used in the correspondence analysis graph for characterization of mite infestations on layer poultry farm workers.

\begin{tabular}{lc}
\hline Variables used in Correspondence Analysis & Abbreviations \\
\hline Manure removal manually & Manu \\
\hline Manure disposal by mechanized conveyor belt & Este \\
\hline Use of acaricides in laying-hen houses & S_Acar \\
Non-use of acaricides in laying-hen houses & N_Acar \\
Presence of $O$. sylviarum & S_Ornit \\
Absence of $O$. sylviarum & N_Ornit \\
Reports of mite attack presence & S_Picad \\
Reports of mite attack absence & N_Picad \\
Manure removal interval $1(0-168$ days $)$ & 1Rem_est \\
Manure removal interval $2(169-336$ days $)$ & 2Rem_est \\
Manure removal interval $3(337-560$ days $)$ & 3Rem_est \\
\hline
\end{tabular}

Ciência Rural, v.50, n.7, 2020. 

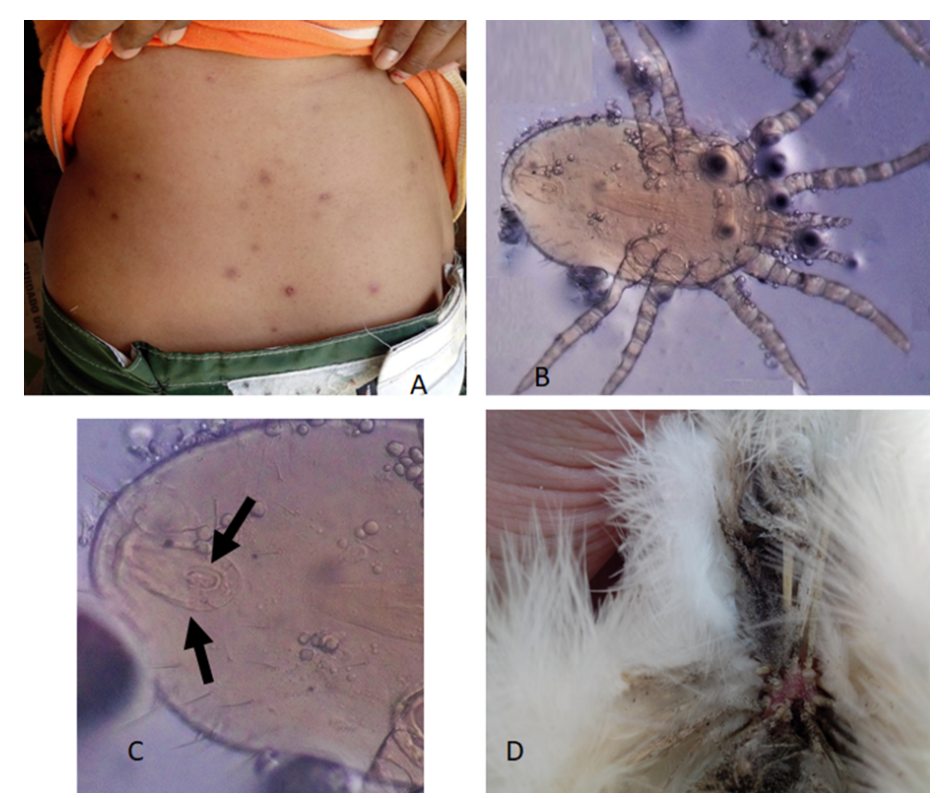

Figure 3 - 3A. Pruritic, erythematous lesions caused by the parasitism of $O$. sylviarum in the abdomen of workers. Figure 3B. O. sylviarum collected in from a commercial laying-hen house from a farm located at the Midwestregion of Minas Gerais state. Figure 3C. The anal plates of $O$. sylviarum being teardrop-shaped (anal plate with anterior opening and anteroposterior tapering shape). Figure 3D.The vent feathers of poultry parasitized by $O$. sylviarum, with infestation index score equal to 7 , that is, with more than 10,000 mites.

These results are consistent with the results of other studies that demonstrated the possibility of the presence and possible survival of hematophagous mites in manure (KIRKWOOD, 1963; TUCCI et al., 1996; NORDENFORS et al., 1999; CHEN \& MULLENS, 2008; TEIXEIRA, 2016).

Mites can actively leave the chickens in search of new hosts, specifically in high infestations in hen houses. Furthermore, when kept without poultry, they can feed from several vertebrate hosts, including humans. Thus, occupational routine on a farm contributes to a possible infestation of $O$. sylviarum in humans. Dermatological examination of the worker revealed the presence of disseminated flat erythematous papules, sometimes with a central vesicle, distributed in the abdominal region (Figure $3 \mathrm{C})$. These symptoms are consistent with other reports that described dermatitis, pruritus, excoriations, allergic reactions, and temporary papular cutaneous lesions caused by Ornithonyssus in humans (SUZUKI et al., 2014; MENTZ et al., 2015).

The dispersion of hematophagous mites on farms is related to infestation level, as observed in this study, in which the birds presented a high degree of infestation by $O$. sylviarum (score equal to 7). This result is consistent with the findings of KIRKWOOD (1963), CHEN \& MULLENS (2008), TEIXEIRA (2016) and MURILLO \& MULLENS (2017) who stated that when the intensity of mite infestation is high, they tend to fall or exit actively from the poultry and are found in the manure underneath cages, in the facilities, and in eggs produced, being capable to survive for a few weeks in the environment. It was noted in the case report that employees had insufficient knowledge about the ectoparasite itself and its biology since part of the population erroneously consider these mites to be "lice." The same was reported by REZENDE et al. (2013), stating that in Brazil, these species of mites are popularly misclassified as "lice." Actually, "lice" are taxonomically referred to as ectoparasites of several families, genera, and species belonging to class Insecta, order Phthiraptera. These parasites are biologically and epidemiologically different from mites and require specific control measures.

The high degree of infestation may contribute to the spread of parasites in the 
environment, being found in the excreta under cages, in eggs produced, and by infesting poultry workers. Hence, possible reinfestations may occur on farms (GUIMARÃES et al., 2001; CHEN \& MULLENS, 2008). In humans, the non-specific dermatitis caused by hematophagous mites of the suborder Mesostigmata is not pathognomonic, which makes the diagnosis difficult and may cause them to be confused with other ectoparasites (ORTON, 2000). It is important to highlight that factors such as identification, analysis of epidemiological conditions, and knowledge regarding the life cycle of $O$. sylviarum are important to establish the accurate diagnosis.

\section{CONCLUSION}

Considering the clinical manifestations in humans and high frequency of occurrences in Minas Gerais, it is suggested that parasitism by $O$. sylviarum should be treated as an occupational hazard affecting employees working in direct contact with commercial egg-laying hens in the state. It is important to highlight that frequent removal of manure manually or by conveyor belt could reduce the presence of this mite in manure and sheds and prevent the possible attacks of this mite on farm workers. Additionally, monitoring the intensity of avian infestation and development of more efficient control strategies of $O$. sylviarum are required from a non-econometric perspective, in addition to the health of nonhuman animals, specifically workers working in direct contact with commercial egg-laying hens, as part of a one-health approach.

\section{ACKNOWLEDGMENTS}

The authors thank the Conselho Nacional de Desenvolvimento Científico e Tecnológico" (CNPq) (scholarship 140646/2012-4) and the funding in partbythe Fundação de Amparo à Pesquisa do Estado do Minas Gerais (FAPEMIG) (Process number: APQ00872/13).

\section{BIOETHICS AND BIOSECURITY COMMITTEE APPROVAL}

The present study was approved by Animal Ethical Committee of the Universidade Federal de Minas Gerais (UFMG) $\operatorname{COEP}\left(\mathrm{n}^{\circ}\right.$ 0238.0.203.000-11) and CEUA ( $\left.\mathrm{n}^{\circ} 74 / 2013\right)$.

\section{DECLARATION OF CONFLICT OF INTERESTS}

The authors declare no conflict of interest. The founding sponsors had no role in the design of the study; in the collection, analyses, or interpretation of data; in the writing of the manuscript, and in the decision to publish the results.

\section{AUTHORS' CONTRIBUTIONS}

All authors contributed equally for the conception and writing of the manuscript. All authors critically revised the manuscript and approved of the final version.

\section{REFERENCES}

AKDEMIR, C. et al. Case report: Dermanyssus gallinae in a patient with pruritus and skin lesions. Türkiye Parazitoloji Derneği, Esmirna, v.33, p.242-244, 2009. Available from: <https://www.researchgate. net/publication/38031470_Case_report_Dermanyssus_gallinae_in_a_ patient_with_pruritus_and_skin_lesions $>$. Accessed: Nov. 20, 2016

ARTHUR, F.H.; AXTELL R.C. Northern fowl mite population development on laying hens caged at three colony sizes. Poultry Science, v.62, p.424 - 427, 1983. Available from: $\quad<$ https://www.sciencedirect.com/science/article/pii/ S0032579119459737?via\%3Dihub>. Accessed: Jan. 20, 2017. doi: $10.3382 /$ ps.0620424.

AXTELL, R.C.; ARENDS, J.J. Ecology and management of arthropod pests of poultry. Annual Review of Entomology, v.35, p.101-126, 1990.Available from: <https://www.annualreviews.org/ doi/pdf/10.1146/annurev.en.35.010190.000533>. Accessed: Jan. 20, 2017. doi: 10.1146/annurev.en.35.010190.000533.

CHEN, B.L.; MULLENS, B.A. Temperature and humidity effects on off host survival of the northern fowl mite (Acari: Macronyssidae) and the chicken body louse (Phthiraptera: Menoponidae). Journal of Economic Entomology, v.101 p.637646, 2008. Available from: <https://academic.oup.com/jee/articleabstract/101/2/637/902882? redirectedFrom=fulltext $>$. Accessed: Feb. 10, 2017. doi: 10.1093/jee/101.2.637.

CUNHA, L.M. Aspectos epidemiológicos relacionados à ocorrência de ácaros hematófagos em granjas comerciais de postura no Estado de Minas Gerais e avaliação de armadilhas para captura de Dermanyssus gallinae (Acari: Dermanyssidae) (De Geer, 1778). 2013. 96f. Tese (Doutorado em Ciência Animal) Escola de Veterinária, Universidade Federal de Minas Gerais, Belo Horizonte. Available from: <http://www.bibliotecadigital.ufmg.br/ dspace/handle/1843/BUBD-9BGJZE>. Accessed: Oct. 10, 2016.

DEVANEY, J.A. A survey of poultry ectoparasite problems and their research in the United States. Poultry Science, v.57, p.1217-1220, 1978. Available from: $\quad<$ https://www.sciencedirect.com/science/article/pii/ S0032579119551793 > . Accessed: Feb. 10, 2017. doi: org/10.3382/ ps.0571217.

DEVANEY, J.A. The effects of the northern fowl mite, Ornithonyssus sylviarum on egg production and body weight of caged white leghorn hens. Poultry Science, v.58, p.191-194, 1979. Available from: <https://www.sciencedirect.com/science/article/ pii/S0032579119553366>. Accessed: Feb. 15, 2017. doi: 10.3382/ ps.0580191.

FACCINI, J.L.H.; MASSARD, C.L. Nota sobre a ocorrência de Ornithonyssus sylviarum (Canestrini e Fanzago) (Mesostigmata: Macronysssidade) em Galllusgallus L. no Brasil. Arquivos da Universidade Federal Rural do Rio de Janeiro, v. 4, p.39-40, 1974. Accessed: Feb. 15, 2017.

FACCINI, J.L.H. Ácaros hematófagos: parasitos de aves de postura (Gallus gallus) no Brasil. Diversificação, biologia e controle. 
Arquivo Fluminense de Medicina Veterinária, v.2, p.29 - 31, 1987. Accessed: Feb. 15, 2017.

FLECHTMANN, C.H.W. Elementos de acarologia. São Paulo: Nobel, 1975. 344p.

GUIMARÃES, J.H., et al. ( $1^{\text {a }}$ Ed) Ectoparasitos de Importância Veterinária. São Paulo: Plêiade/FAPESP, 2001. 218p.

KIRKWOOD, A.C. Longevity of the mites Dermanyssus gallinae and Liponyssus sylviarum. Experimental Parasitology, v.14, p.358-366, 1963. Available from: <https://www.sciencedirect. com/science/article/abs/pii/0014489463900432>. Accessed: Jul. 01, 2017. doi: org/10.1016/0014-4894(63)90043-2.

KNEE, W.; PROCTOR, H. Host records for Ornithonys sussylviarum (Mesostigmata: Macronyssidae) from birds of North America (Canada, United States and Mexico). Journal of Medical Entomology, v.44, p.709-713, 2007. Available from: <https:// academic.oup.com/jme/article-abstract/44/4/709/877083?redirecte $\mathrm{dFrom}=$ fulltext $>$. doi: 10.1093/jmedent/44.4.709.

KRANTZ, G.W.A. Manual of Acarology. 2.ed. Corvallis: Oregon State University Book Stores, Inc. 1978. 509 p. Ilust.

MENTZ, M.B., et al. Dermatitis caused by the tropical fowl mite Ornithonyssus bursa (Berlese) (Acari: Macronyssidae): a case report in humans. Revista da Sociedade Brasileira de Medicina Tropical, v.48, p.786-788, 2015. Available from: $<$ http://www.scielo. br/scielo.php?script $=$ sci arttext\&pid=S0037-86822015000600786>. Accessed: Jul. 01, 2017.doi: org/10.1590/0037-8682-0170-2015.

MINGOTI, S.A. Análise de dados através de métodos de estatística multivariada - uma abordagem aplicada. Belo Horizonte: UFMG, 2005. Cap. 8, p. 257 - 267.

MOSS, W.W. An illustrated key to the species of the acarine genus Dermanyssus (Mesostigmata: Laelapoidea: Dermanyssidae). Journal of Medical Entomology, v.5, n.1, p.67-84, 1968.Available from: $<$ https://academic.oup.com/jme/article-abstract/5/1/67/2221837>. Accessed: Jul. 01, 2017. doi: 10.1093/jmedent/5.1.67

MULLENS, B.A., et al. Dispersal of northern fowl mites, Ornithonyssus sylviarum, among hens in an experimental poultry house. Journal of Applied Poultry Research, v.10, p.60-64, 2001. Available from: <https://www.sciencedirect.com/science/ article/pii/S1056617119310025>. Accessed: Jul. 01, 2017. doi: 10.1093/japr/10.1.60

MULLENS, B.A., et al. Temporal changes in distribution, prevalence and intensity of northern fowl mite (Ornithonyssus sylviarum) parasitism in commercial caged laying hens, with a comprehensive economic analysis of parasite impact. Veterinary Parasitology, v.160, p.116-133, 2009. Available from: <https://www.sciencedirect. com/science/article/abs/pii/S0304401708005980>Accessed: Jul. 01, 2017.doi:10.1016/j.vetpar.2008.10.076.

MURILLO, A.C., et al. A review of the biology, ecology, and control of the northern fowl mite, Ornithonyssus sylviarum (Acari: Macronyssidae). Veterinary Parasitology, v.246, p.30-37, 2017 Available from: <https://www.sciencedirect.com/science/article/ abs/pii/S0304401717303801?via\%3Dihub>. Accessed: Jan. 10, 2018. doi: 10.1016/j.vetpar.2017.09.002.

QGIS - Versão 2.18.1 Software gratuito.Accessed: Nov. 20, 2016. Online. Available from: $<$ http://www.qgis.org/en/site/ $>$. Accessed: Jan. 10, 2018. NORDENFORS, H., et al. Effects of temperature and humidity on oviposition, molting, and longevity of Dermanyssus gallinae (Acari: Dermanyssidae). Journal of Medical Entomology, v.36, p.68-72, 1999. Available from: <https://academic.oup.com/ jme/article-abstract/36/1/68/876355? redirectedFrom $=$ fulltext $>$. Accessed: Jul. 01, 2018. doi: 10.1093/jmedent/36.1.68.

OLIVEIRA, T.M., et al. Epidemiological characterization and risk assessment associated with the presence of Diptera order in laying poultry farms. Acta ScientiaeVeterinariae, Porto Alegre, v.46, 1563, 2018. Available from: <https://seer.ufrgs.br/ ActaScientiaeVeterinariae/article/view/83468/48525>. Accessed: Jul. 10, 2018. doi: 10.22456/1679-9216.83468.

ORTON, W.W. Avian mite dermatitis. Clinical and Experimental Dermatology, v.25, p.129-131, 2000, Available from: <https:// onlinelibrary.wiley.com/doi/abs/10.1046/j.13652230.2000.00 594.x? sid=nlm\%3Apubmed $>$. Accessed: Feb. 10, 2017. doi: 10.1046/j.1365-2230.2000.00594.x.

PEREIRA, M.C., et al. Ornithonyssus sylviarum (Canestrini e Fanzago, 1877) em Gallus gallus domesticus (L.) no Estado de São Paulo, Brasil. Revista da Faculdade de Medicina Veterinária e Zootecnia da Universidade de São Paulo, São Paulo, v.14, p.243-251, 1977.Available from: <http://www.periodicos.usp. br/rfmvzusp/article/view/56357>. Accessed: Feb. 20, 2017. doi: org/10.11606/issn.2318-3659.v14i2p243-251.

REZENDE, L.C., et al. Mites affecting hen egg production: some considerations for Brazilian farms. Ciência Rural, Santa Maria, v.43, p.1230-1237, 2013.Available from: <http://www.scielo. br/scielo.php?pid $=$ S0103-84782013005000088\&script $=$ sci arttext>. Accessed: Jan. 20, 2017. doi: org/10.1590/S010384782013005000088 .

REZENDE, L.C., et al. Synanthropicdiptera affecting layer poultry farms: a review. Arquivos do Instituto Biológico, São Paulo, v.86, p.1-8, e0922017, 2019. Available from: <http://www.scielo.br/ scielo.php?pid $=$ S180816572019000100600\&script $=$ sci_arttext $>$. Accessed: jun. 20, 2019. doi: 10.1590/1808-1657000922017.

STATACORP. 2011. Stata Statistical Software: Release 12. College Station, TX: StataCorp LP.

SUZUKI, C.M.P., et al. Gamasoidose ou dermatite por ácaros aviários: relato de caso. Diagnóstico \& Tratamento, Botucatu,v.19, p.74-76, 2014.Availablefrom: <http://www.apm.org.br/imagens/ Pdfs/revista-120.pdf\#page=22> . Accessed: Feb. 20, 2017.

TEIXEIRA, C.M. Dinâmica populacional e controle estratégico de Ornithonys sussylviarum (ACARI: MACRONYSSIDAE) em granjas comerciais de postura de Minas Gerais, Brasil. 2016. 80f. Tese (Doutorado em Ciência Animal) - Escola de Veterinária, Universidade Federal de Minas Gerais, Belo Horizonte. Available from: <http://www.bibliotecadigital.ufmg.br/dspace/handle/1843/ SMOC-AKGJ9L>. Accessed: Oct. 15, 2016.

TÉLLEZ, M.L., et al. Dermatosis por ácaros de palomas: primer reporte de la presencia de Ornithonyssus sylviarum en el Perú. Folia dermatol Peru. v.19, p.63-68, 2008. Available from: $<$ http://200.62.146.19/BVRevistas/folia/vol19_n2/pdf/a02v19n2. pdf $>$. Accessed: Feb. 18, 2017.

TUCCI, E.C., et al. Ocorrência de ácaros hematófagos em aviários de postura no Estado de São Paulo. Revista Brasileira de Parasitologia Veterinária, Jaboticabal, v.5, p.95-102, 1998. Availablefrom: <http://www.ufrrj.br/rbpv/711998/c7171 78.pdf $>$. Accessed: Feb. 20, 2017. 